\title{
Summer temperature affects the ratio of radial and height growth of Scots pine in northern Finland
}

\author{
Hannu SALMINEN*, Risto JALKANEN, Markus LINDHOLM \\ Finnish Forest Research Institute, Rovaniemi Research Unit, P.O. Box 16, 96301 Rovaniemi, Finland
}

(Received 27 June 2008; revised version 27 February 2009; accepted 24 March 2009)

Keywords: autocorrelation / dendroclimatology / Pinus sylvestris / temperature / tree line

\begin{abstract}
- Radial and height growth chronologies from 150-year-old and 50-year old Scots pine stands, both located near to the northern timberline in Laanila, Finland $\left(68^{\circ} 30^{\prime} \mathrm{N}, 27^{\circ} 28^{\prime} \mathrm{E}\right)$, were crosscorrelated with each other and with mean temperatures of various temperature periods defined as months, days or growing-degree-days.

- The height-growth chronology correlates significantly with radial growth at lags 1 and 2, and radial growth with height growth at lag 2 when the effect of temperature is omitted. On average, low and high growth years represent cool and warm average growing seasons. The summer temperatures (June, July and August) affect most on growth, but height and radial growth do have a different set of effective temperature periods. Furthermore, July temperature variation affects stronger height than radial growth.

- Those years with low height/radial-growth ratio, i.e. relatively higher current year's radial than next year's height growth, do have lower growth and cooler-than-average July temperature whereas those years with high height/radial-growth ratio do have clearly warmer mid-summer temperatures.
\end{abstract}

\author{
Mots-clés : \\ autocorrélation / \\ dendroclimatologie / \\ Pinus sylvestris / \\ température / \\ limite des arbres
}

\begin{abstract}
Résumé - Les températures estivales influent sur le rapport croissance en hauteur et croissance radiale chez le pin sylvestre dans le nord de la Finlande.

- Les chronologies de croissance en hauteur et de croissance radiale de peuplements de pins sylvestres âgés de 50 et 150 ans, localisés près de la limite septentrionale de la forêt à Laanila en Finlande ( $68^{\circ}$ $30^{\prime} \mathrm{N}, 27^{\circ} 28^{\prime} \mathrm{E}$ ), ont été inter-corrélées entre elles et avec les températures moyennes de différentes périodes de températures définies en terme de mois, de jours ou de degrés jours de période de croissance.

- La chronologie de la croissance en hauteur a été significativement corrélée avec la croissance radiale avec un retard de 1 à 2 , et la croissance radiale avec la croissance en hauteur avec un retard de 2 quand l'effet de la température n'est pas pris en compte. En moyenne, les années à croissance élevée et faible représentent des saisons de végétation en moyenne chaudes et fraîches. Les températures estivales (juin, juillet, août) affectent fortement la croissance, mais la croissance radiale et la croissance en hauteur ont un jeu différent de périodes de températures efficaces. En outre, la variation de température de juillet influe plus fortement sur la croissance en hauteur que sur la croissance radiale. - Ces années avec un rapport croissance en hauteur/croissance radiale bas, c'est-à-dire une croissance radiale de l'année en cours relativement plus élevée que la croissance en hauteur de l'année suivante, ont une croissance plus faible et une température plus fraîche que la température moyenne de juillet, alors que ces années avec un rapport croissance en hauteur/croissance radiale élevé ont des températures de milieu d'été nettement plus chaudes.
\end{abstract}

\section{INTRODUCTION}

Tree-ring and height-growth measurements of a tree consist of sequential observations and are in that sense typical time series. Most time series can be described in basic terms such as trends, serial dependency (autocorrelation), and the remaining (residual) variation called white noise (Harvey, 1993). Trends and autocorrelation can be modelled and mathematically formulated and utilized in interpretations and predictions but, on the other hand, they disturb the independence of observations and make analysis of time series more complex.

\footnotetext{
*Corresponding author: hannu.salminen@metla.fi
} 
The form and magnitude of autocorrelation can reveal causalities between time series. For example, biological time series often are autocorrelated because carbohydrates produced in one year are used both in the same and next years. There are also obvious structural reasons; active meristems depend on supporting and vascular tissues that are formed during previous growing seasons. The older organs may have only limited ability to change their structural characteristics that initially reflect the growth conditions of the time when they were formed. Niinemets (1997) exemplifies that the old leaves of evergreen species cannot adjust their stomatal density and number of layers of mesophyll cells. This example may be reformulated into the following hypothesis; high needle retention indicates higher autocorrelation of tree growth. In addition to the growth process itself, autocorrelation in measured growth series may be caused by serial correlation in environmental conditions affecting growth directly or indirectly. For example, geophysical time series that describe environmental conditions may be autocorrelated because of intertia and buffering in the physical system such as groundwater balance.

Time series may comprise trends of different frequencies. The aim of every analysis defines which trends are interesting and which are disturbing components. The analysis of an agedependent growth trend can be the main result of a growth and yield study, whereas in dendroclimatological analysis all nonclimatic trends must be removed from the studied data (Bower et al., 2005). Trends in tree growth can be divided into those due to internal factors such as changes in tree architecture and physiology, and those caused by external factors like changes in the environment. Growth of trees usually follows a sigmoid curve where maximum rate is reached at a rather young age, and thereafter it gradually decreases. When cross-correlating two time-series at least one of them must be detrended and autocorrelation must be removed (the series is prewhitened) to prevent any spurious correlation due to similar trends and autocorrelation structure of the series.

The height growth of monocyclic pines is predetermined; the growth initials are laid down in the bud in the year preceding the actual elongation (Doak, 1935; Lanner, 1976) and the growing conditions during bud formation largely define the next year's shoot length (Junttila, 1986; Lanner, 1985). Radial growth is affected mainly by the conditions of the current growing season (Hustich, 1948; Jalkanen and Tuovinen, 2001; Mikola, 1950). Therefore, ring width of one year and the next year's height growth are paired variables. The dependence of radial growth on current summer temperature and the dependence of height growth on previous summer temperature at high latitudes are widely known (Hustich, 1948; Jalkanen and Tuovinen, 2001; Junttila and Heide, 1981; Laitakari, 1920; Mikola, 1950; Salminen and Jalkanen, 2005). Radial and height growth define the volume growth and form of the main trunk, and they have been explored in numerous growth and yield studies. Their relationship is also interesting because it reflects the carbon allocation of a tree. Still, the statistical dependence between radial and height growth is less known, and the effect of temperature on both of these growth series has not been studied simultaneously using long timeseries mainly due to lack of appropriate height-growth data.

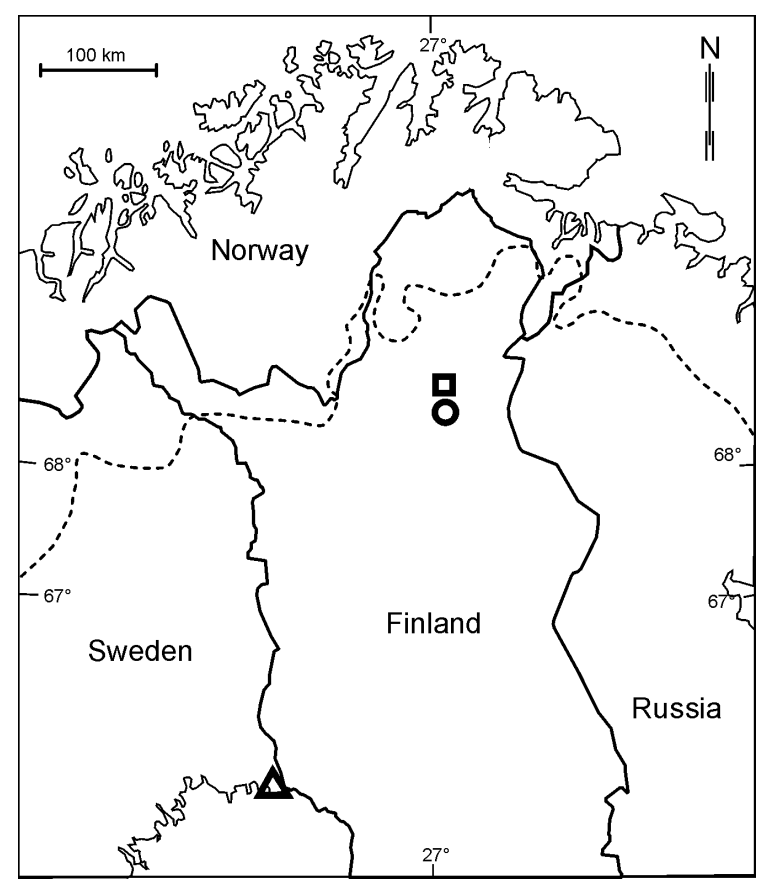

Figure 1. Location of the experimental stands (circle), weather stations (box and triangle), and the northern timberline of Scots pine in Finland.

The most common way to include meteorological data in dendrochronological studies is to use mean monthly values. Partly this is due to practical reasons; monthly values are easier to obtain, but also due to the assumption that monthly resolution is precise enough. This may be true in most cases. Nevertheless, in the field of dendroecology or when examining intraannual phenomenon such as phenology, it is reasonable to use daily if not even hourly observations.

The aim of the study is to examine the relationship between growth components (radial and height growth). This is done by following steps: model the autocorrelation structure of height and radial-growth series measured from the same trees, construct respective stand-wise chronologies based on the tree-wise measurements, and finally, examine the relationship between growth components and temperature variables. The ratio of height and radial growth is used to reveal possible differences in climate-induced changes in growth allocation. In addition to mean monthly values, temperature periods that were defined as days and growing-degree-days were explored.

\section{MATERIAL AND METHODS}

\subsection{Empirical material}

Annual height and radial growth were measured from two adjacent Scots pine stands located near to the northern timberline in Laanila, Finland (68 $30^{\prime} \mathrm{N}, 27^{\circ} 28^{\prime} \mathrm{E}$, altitude $220 \mathrm{~m}$ ) (Fig. 1). From stand 1, 10 sample trees were selected. Selection was based on absence of visual signs of disturbances or suppressions. Their mean height, diameter and age were $17.6 \mathrm{~m}, 30.5 \mathrm{~cm}$, and $158 \mathrm{y}$, respectively. From 
Table I. Sample tree characteristics.

\begin{tabular}{lcc}
\hline Stand & 150-year-old & 50-year-old \\
\hline Mean, min. and max. age & $158(137-178)$ & $42(32-49)$ \\
at breast height, y & $30.5(27-35)$ & $14.7(13-17)$ \\
Mean, min. and max. dbh, cm & $17.6(14-20)$ & $10.9(8-14)$ \\
Mean, min. and max. height, m & $2003: 5$ & $2000: 5$ \\
Sampling year: number of sample trees & $2005: 5$ & $2001: 5$ \\
& & $2002: 5$ \\
& & $2003: 5$ \\
Total number of sample trees & 10 & $2004: 5$ \\
\hline
\end{tabular}

stand 2, a total of 25 sample trees were selected from open-grown dominant trees that were visually assessed to be healthy with straight, unbroken stems and regular-shaped crowns and not suppressed by competition. The mean height and breast-height diameter of the sample trees in the stand 1 were $17.6 \mathrm{~m}$ and $30.5 \mathrm{~cm}$, respectively, and the mean age at breast height was $42 \mathrm{y}$ (Tab. I). At the time of sampling these trees were dominant but their past history is less known. The stand 1 is located near the old main road from Sodankylä to Ivalo that was built in 1914, and there was a military camp nearby in 19441945. The forest area was inventoried for the first time in 1940, and at that time the dominant age of the stand compartment with the stand 1 was $110 \mathrm{y}$. There have been selection fellings for fuel and construction timber in the area, indicated by some stumps found in the sample site in 2000 . Hereafter the stands 1 and 2 are referred to as the "150year-old" and "50-year-old" stands.

The sample trees were felled in the years 2000-2005 and analysed according to the Needle Trace Method, NTM (Kurkela and Jalkanen, 1990) that aims to produce consistent time series of annual needle dynamics as well as height and radial growth. The height increments were measured in the field from felled trees along the main trunk from 1.3 m upwards (Aalto and Jalkanen, 1998). The height growth of pine in the north is rarely undisturbed (Hustich, 1948; 1978). Therefore, annual rings and shoots were crosschecked to reveal possible leader changes that were already healed over and hidden inside the trunk. Obscure annual shoots were marked and collected for a recheck in the laboratory, where they were sawn up and analysed (Aalto and Jalkanen, 1998). As compared to traditional height growth measurements, this procedure is laborious because it necessitates tree felling and laboratory analysis but, on the other hand, the results are precise. The method also results in long time series in height increment, which have been rare so far.

In this study, annual shoots affected by leader change were marked as missing values. The gaps were filled using procedure included in the recent version of program ARSTAN (Büntgen et al., 2006). This gap-filling procedure comprises averaging the annual measured growth data and adjusting the variance of the mean values to the variance of the measurement series.

Monthly mean temperature records covering years from 1958 onwards and daily temperature values from 1961 onwards were obtained from the Ivalo weather station of the Finnish Meteorological Institute $\left(68^{\circ} 40^{\prime} \mathrm{N}, 27^{\circ} 34^{\prime} \mathrm{E}\right)$. To cover the whole study period, the mean monthly temperatures of the years 1802-1957 from Tornedalen (Klingbjer and Moberg, 2003) were adjusted to the same level with Ivalo using the mean monthly differences to Ivalo data during their common period 1958-2002.

\subsection{Methods}

The cross-dating of individual height and radial-growth series of the trees were checked using cross-correlations by the program COFECHA (Grissino-Mayer, 2001; Holmes 1983). The autocorrelation structure and parameters of the gap-filled and cross-checked series were modelled using program ARSTAN (Cook et al., 1990a; Grissino-Mayer et al., 1993) and SAS ARIMA (SAS User's Guide, 2002). The orders of AR or ARMA models were identified by the smallest canonical correlation method (Tsay and Tiao, 1985) implemented in SAS ARIMA.

The autocorrelation structure of the series was studied using two approaches. First, both radial and height growths of each tree were analyzed separately to determine the within-stand variability. Second, the measurements were averaged as raw data chronologies that represent the common growth pattern of a stand, and the autocorrelation of these chronologies were modelled.

Stand-wise chronologies were produced by detrending procedure (Holmes et al., 1986), which objectively removes the low-to-mediumfrequency disturbance components from the data. Flexible splines (30-year-long) were fitted to individual series. Thereafter, the detrended series were prewhitened using the autocorrelation-modelling feature of ARSTAN. It selects the appropriate model based on the minimum Akaike information criterion (AIC). The mean index value for each year was calculated using the biweight robust mean method (Cook et al., 1990b).

As a result of the detrending and prewhitening process, two types of stand chronologies were developed: the mean of indices before AR modelling (standard chronology), and the mean of indices after AR modelling of individual series (residual chronology) (GrissinoMayer et al., 1993). The qualities of chronologies were assessed on the basis of the following statistical parameters which are expected to indicate the strength of a common signal and climatic influence on tree growth: standard deviation (SD), mean sensitivity (MS), signalto-noise ratio (SNR), and the mean correlation coefficient for all possible pairings among tree-wise series from an individual chronology (Rbar), computed for a specific common time interval (Briffa, 1995; Briffa and Jones, 1990).

The dependence of growth and mean monthly temperatures as well as the dependence between radial and height growth was studied by cross-correlation analysis. The analyses were based on residual chronologies that were stationary and white noise. The standard chronologies were used when solving the parameters of vector autoregressive moving average models of radial and height growth (SAS User's Guide, 2002). For example, a tree growth model of order one can be written as follows:

$$
\left\{\begin{array}{l}
i D_{t}=c_{1}+\phi_{11} i D_{t-1}+\phi_{12} i H_{t-1}+\Theta_{1}^{*} x_{t-1}+\varepsilon_{1 t} \\
i H_{t}=c_{2}+\phi_{21} i H_{t-1}+\phi_{22} i D_{t-1}+\Theta_{2}^{*} x_{t-1}+\varepsilon_{2 t}
\end{array}\right.
$$

where $i D$ and $i H$ are observation vectors (radial and height growth of year $t$ ), $x$ is a vector of exogenous variables such as temperature series, $\varepsilon$ is a white noise vector, $c$ is a vector of parameters, and matrices $\varnothing$ and $\Theta_{i}^{*}$ comprise autoregressive parameters.

In addition to mean monthly temperatures, also daily values were used from 1961 onwards. A direct-search algorithm was used in order to screen for the temperature periods yielding the best fit with the growth series, radial and height growth of each stand separately. The start and end of these temperature periods were defined using either Julian calendar or relative growing-degree-day. The latter was defined as the proportion of the accumulated degree-days (threshold 
Table II. Autocorrelation and partial autocorrelations (acf and pacf), and the coefficients (AR model) and fit (root mean square, RSQ) of the autoregressive model of the measured (raw data) chronology based on the common years of height and radial growth measurements of each tree.

\begin{tabular}{|c|c|c|c|c|c|c|c|c|c|c|c|c|}
\hline \multirow{2}{*}{$\begin{array}{l}\text { Growth } \\
\text { series }\end{array}$} & \multirow{2}{*}{$\begin{array}{c}\text { Series } \\
\text { length, } \\
\text { years }\end{array}$} & & \multicolumn{10}{|c|}{ Lag } \\
\hline & & & $t-1$ & $t-2$ & $t-3$ & $t-4$ & $t-5$ & $t-6$ & $t-7$ & $t-8$ & $t-9$ & $t-10$ \\
\hline \multirow[t]{4}{*}{ Radial } & 150 & acf & 0.798 & 0.707 & 0.659 & 0.601 & 0.557 & 0.545 & 0.549 & 0.464 & 0.433 & 0.417 \\
\hline & & pacf & 0.798 & 0.194 & 0.142 & 0.029 & 0.036 & 0.103 & 0.117 & -0.175 & 0.024 & 0.033 \\
\hline & & $95 \%$ c.l. & 0.149 & 0.225 & 0.270 & 0.304 & 0.330 & 0.350 & 0.369 & 0.386 & 0.399 & 0.409 \\
\hline & & AR model & 0.607 & 0.124 & 0.132 & RSQ 0.662) & & & & & & \\
\hline \multirow[t]{4}{*}{ Height } & 150 & acf & 0.737 & 0.645 & 0.610 & 0.544 & 0.586 & 0.552 & 0.522 & 0.485 & 0.471 & 0.447 \\
\hline & & pacf & 0.737 & 0.223 & 0.176 & 0.022 & 0.244 & 0.022 & 0.039 & -0.033 & 0.075 & -0.027 \\
\hline & & $95 \%$ c.l. & 0.149 & 0.216 & 0.255 & 0.286 & 0.308 & 0.332 & 0.352 & 0.369 & 0.383 & 0.396 \\
\hline & & AR model & 0.532 & 0.123 & 0.179 & (RSQ 0.583) & & & & & & \\
\hline \multirow[t]{4}{*}{ Radial } & 50 & acf & 0.469 & 0.419 & 0.406 & 0.348 & 0.164 & 0.440 & 0.309 & 0.210 & 0.297 & 0.336 \\
\hline & & pacf & 0.469 & 0.256 & 0.191 & 0.081 & -0.162 & 0.390 & -0.002 & -0.095 & 0.126 & 0.070 \\
\hline & & $95 \%$ c.l. & 0.277 & 0.333 & 0.371 & 0.404 & 0.426 & 0.431 & 0.464 & 0.480 & 0.487 & 0.501 \\
\hline & & AR model & 0.255 & 0.233 & 0.215 & (RSQ 0.338) & & & & & & \\
\hline \multirow[t]{4}{*}{ Height } & 50 & acf & 0.341 & 0.057 & 0.064 & -0.164 & -0.252 & 0.102 & 0.037 & -0.149 & 0.081 & 0.044 \\
\hline & & pacf & 0.341 & -0.067 & 0.075 & -0.238 & -0.132 & 0.274 & -0.089 & -0.177 & 0.135 & -0.013 \\
\hline & & $95 \%$ c.1. & 0.277 & 0.308 & 0.309 & 0.310 & 0.316 & 0.331 & 0.334 & 0.334 & 0.339 & 0.341 \\
\hline & & AR model & 0.344 & (RSQ 0.123) & & & & & & & & \\
\hline
\end{tabular}

$+5{ }^{\circ} \mathrm{C}$ ) with respect to the long-term average of annual degree-day sum between April 1st and September 30th.

\section{RESULTS}

The most common autocorrelation model recommendation for the 150-year-old trees, based on smallest canonical correlation was $\operatorname{AR}(1)$ or $\operatorname{ARMA}(1,1)$. When modelling the raw data chronology, a higher order AR(3) model was selected based on AIC (Tab. II). The mean autocorrelation coefficients were at the same level both in radial and height growth of the 150-year-old stand. Between-tree variation in the 150-year-old stand was small; all the trees and both growth series had statistically significant autocorrelation at lags 1-3.

One third of the 50-year-old trees carried a statistically significant autocorrelation in radial growth at lags 1-3. About half of the trees autocorrelated significantly at lag 1 and some of them also at lag 2, and two trees had no significant autocorrelation at all. The most common ARMA model recommendations at individual tree level were $(1,0)$ and $(3,1)$. The autoregressive model selected for stand-level radial-growth chronology according to the smallest AIC value was AR(3). In the 50-year-old stand, about half of the trees had no statistically significant autocorrelation in height growth. The rest of the trees had a significant autocorrelation at lag 1 but not at longer lags. The AR model for stand-level height-growth chronology was AR(1). The autocorrelation of radial growth was higher and at longer lags than the autocorrelation of height growth. Different length of growth series may have affected differences in age trend and autocorrelation modelling of the 50 and 150-year-old trees. Fitting the model to the early years of the 150-old-trees tested this. The results were consistent with the model based on the entire time series.
Table III. Characteristics of the residual chronologies of Scots pine. MS is the mean sensitivity, Rbar is the mean correlation between indices for each year.

\begin{tabular}{lcccccc}
\hline $\begin{array}{l}\text { Growth } \\
\text { series }\end{array}$ & $\begin{array}{c}\text { Length, } \\
\text { years }\end{array}$ & Chronology & $\begin{array}{c}\text { Number } \\
\text { of series }\end{array}$ & St. dev & MS & Rbar \\
\hline Radial & 150 & Res. & 10 & 0.17 & 0.18 & 0.42 \\
Height & 150 & Res. & 10 & 0.30 & 0.31 & 0.39 \\
Radial & 50 & Res. & 24 & 0.12 & 0.13 & 0.43 \\
Height & 50 & Res. & 25 & 0.19 & 0.24 & 0.55 \\
\hline
\end{tabular}

There is a substantial difference between the growth-rate of the 50 and 150-year-old trees. In general, the 50-yearold trees have higher growth rates and reach their maximum growth at 15-20 year's breast-height age. The 150-year-old trees have grown slowly during their juvenile phase when their age-dependent growth trend was weak. During 1910-1930 the growth of the 150-year-old trees accelerated, and the diameter growth remained at a higher level but annual height growth gradually ceased back to $10-20 \mathrm{~cm}$.

The basic dendrochronological properties of the residual chronologies indicate that height growth has more variation and is more sensitive than radial growth but in terms of Rbar the quality of both chronologies is alike (Tab. III).

The dependence between mean monthly temperature and growth was studied by cross-correlating residual chronologies and temperature series at various lags. According to the results, the summer temperatures (June, July and August) affect growth most, but height and radial growth do have a different set of effective months especially in the 50-year-old stand (Tab. IV). The correlation coefficients between height growth and monthly temperatures were higher than those between radial growth and temperature. Furthermore, especially height but also diameter growth of the 50-year-old stand had stronger 
Table IV. Cross-correlation of residual chronologies of Scots pine and mean monthly temperature of June, July and August at lags 0 and 1 for years 1848-2005 (150-years old stand) or 1957-2004 (50-years old stand). Statistically significant $(r>2 \cdot$ std.err.) correlation coefficients are underlined.

\begin{tabular}{|c|c|c|c|c|c|}
\hline \multirow[b]{2}{*}{$\overline{\mathrm{Lag}}$} & \multirow[b]{2}{*}{ Month } & \multicolumn{2}{|c|}{$\begin{array}{l}\text { 150-year-old trees } \\
\text { (std.err. } 0.080 \text { ) }\end{array}$} & \multicolumn{2}{|c|}{$\begin{array}{l}\text { 50-year-old trees } \\
\text { (std.err. 0.144) }\end{array}$} \\
\hline & & $\begin{array}{l}\text { Radial } \\
\text { growth }\end{array}$ & $\begin{array}{l}\text { Height } \\
\text { growth }\end{array}$ & $\begin{array}{l}\text { Radial } \\
\text { growth }\end{array}$ & $\begin{array}{l}\text { Height } \\
\text { growth }\end{array}$ \\
\hline$\overline{t-1}$ & June & 0.16 & 0.19 & -0.08 & 0.42 \\
\hline$t-1$ & July & -0.07 & $\overline{0.38}$ & 0.09 & $\overline{0.75}$ \\
\hline$t-1$ & Aug & -0.10 & $\overline{0.16}$ & 0.06 & 0.54 \\
\hline 0 & June & 0.13 & 0.16 & 0.19 & 0.38 \\
\hline 0 & July & $\underline{0.39}$ & $\overline{0.06}$ & $\underline{0.41}$ & $\overline{0.14}$ \\
\hline 0 & Aug & $\overline{0.10}$ & -0.13 & $\overline{0.18}$ & -0.02 \\
\hline
\end{tabular}

Table V. The cross-correlation coefficients between radial and height growth residual chronologies of the 150 and 50-year-old Scots pine stands. Statistically significant $(r>2 \cdot$ std.err.) correlation coefficients are underlined.

\begin{tabular}{lrrrr}
\hline & Height vs. radial growth & $\begin{array}{c}\text { 150 vs. 50-year-old stand } \\
\text { (common years) }\end{array}$ \\
\hline Lag & $\begin{array}{r}\text { 150-year-old stand 50-year-old stand Radial growth Height growth } \\
\text { (std.err. 0.08) }\end{array}$ & (std.err. 0.14) & (std.err. 0.14) & (std.err. 0.14) \\
\hline$t-4$ & -0.02 & -0.09 & 0.10 & -0.13 \\
$t-3$ & -0.09 & -0.21 & 0.10 & 0.26 \\
$t-2$ & $\underline{-0.21}$ & -0.11 & -0.27 & -0.21 \\
$t-1$ & $\underline{0.23}$ & $\underline{0.42}$ & -0.15 & -0.19 \\
0 & 0.06 & $\underline{0.29}$ & $\underline{0.38}$ & $\underline{0.51}$ \\
$t+1$ & 0.05 & -0.25 & -0.20 & -0.08 \\
$t+2$ & $\underline{0.23}$ & $\underline{0.29}$ & -0.18 & -0.23 \\
$t+3$ & 0.03 & 0.01 & 0.14 & 0.05 \\
$t+4$ & -0.02 & 0.08 & 0.12 & -0.02 \\
\hline
\end{tabular}

relation to temperature than the 150-year-old stand. Height growth of both stands correlated also with current June temperature.

The dependence between radial and height growth was analysed by cross-correlating the residual chronologies. The scores were rather low albeit statistically significant (Tab. V). Height-growth chronology of the 150-year-old stand correlated significantly with radial growth at lags 1 and 2, whereas similar analysis with the 50-year-old stand resulted in lag 0 and 1. Radial growth of both stands had a statistically significant correlation with height growth at lag 2 . The chronologies of the two stands yielded higher correlation with height than radial growth.

Vector autoregressive models were analysed using mean temperature of the most effective month, i.e. July, as an exogenous variable. It affects radial growth of the current season and height growth of the following season. The dependence of radial and height growth is partly due to the effect of temperature although there is still feedback between growth chronologies. To be more specific, height growth at lag 2 was a statistically significant independent variable in both models of radial growth (Tab. VI). July temperature affects stronger height than radial growth; the estimated July temperature coefficients of
Table VI. Parameters of the vector autoregressive model of tree growth based on standard growth chronologies.

\begin{tabular}{|c|c|c|c|c|c|c|}
\hline Stand & Series & Parameter & Estimate & Error & value $\operatorname{Pr}>|t|$ & $R$-square \\
\hline \multirow{9}{*}{ 150-year-old } & \multirow[t]{4}{*}{ Radial } & constant & 0.24 & 0.11 & 2.30 .0251 & \multirow[t]{4}{*}{0.26} \\
\hline & & $\operatorname{Jul}(t)$ & 0.03 & 0.01 & 5.20 .0001 & \\
\hline & & $i D(t-1)$ & 0.27 & 0.07 & 3.80 .0002 & \\
\hline & & $i H(t-2)$ & 0.08 & 0.04 & 2.30 .0217 & \\
\hline & \multirow{5}{*}{ Height } & constant & 0.61 & 0.21 & 2.90 .0048 & \multirow[t]{5}{*}{0.33} \\
\hline & & $\operatorname{Jul}(t-1)$ & 0.06 & 0.01 & 5.90 .0001 & \\
\hline & & $\operatorname{Jul}(t-2)$ & -0.04 & 0.13 & $\begin{array}{ll}-3.3 & 0.0013\end{array}$ & \\
\hline & & $\mathrm{iH}(t-1)$ & 0.39 & 0.07 & 5.30 .0001 & \\
\hline & & $\mathrm{iD}(t-2)$ & -0.32 & 0.14 & $\begin{array}{ll}-2.2 & 0.0293\end{array}$ & \\
\hline \multirow{6}{*}{ 50-year-old } & \multirow[t]{4}{*}{ Radial } & constant & 0.78 & 0.15 & 5.10 .0001 & \multirow[t]{4}{*}{0.39} \\
\hline & & $\operatorname{Jul}(t)$ & 0.02 & 0.01 & 3.30 .0019 & \\
\hline & & $\operatorname{Jul}(t-2)$ & -0.02 & 0.01 & -2.60 .0249 & \\
\hline & & $\mathrm{iH}(t-2)$ & 0.15 & 0.06 & 2.30 .0312 & \\
\hline & \multirow[t]{2}{*}{ Height } & constant & -0.30 & 0.13 & -2.20 .0312 & \multirow[t]{2}{*}{0.68} \\
\hline & & $\operatorname{Jul}(t-1)$ & 0.09 & 0.01 & 9.90 .0001 & \\
\hline
\end{tabular}

height-growth models were higher than those of radial-growth models especially for the 50-year-old stand (Tab. VI). In addition to July, some other monthly temperatures were statistically significant but - according to AIC - they did not improve the fit of the models and were omitted. There is also considerable amount of residual variation particularly in models of radial growth and height growth of the 150-year-old stand.

Height and radial-growth chronologies have better year-toyear agreement to the same chronology of the other stand than the other chronology of the same stand (Tab. V). The chronologies of the same stand agree in most of the cases but there are years when a good radial growth is not followed by a good height increment or low radial-growth is not followed by low height-increment one year later (Fig. 2).

Those years when measured radial and height-growth series had contradictory growth indices, either high-low or low-high (Fig. 2), were studied for common temperature patterns expressed as mean monthly values. As expected, growing seasons of low growth are cool and those of high growth are warm. In general, those years with low height/radial-growth ratio, i.e. relatively higher current year's radial than next year's height growth, do have lower growth and cooler-than-average July temperature, whereas those years with high height/radialgrowth ratio do have clearly warmer mid-summer temperatures, as exemplified in the years of 1870, 1896, 1919, 1927, 1938 , and 1966. Also this suggests that height growth is more sensitive to July temperature than radial growth.

There are exceptions to observed common temperature dependency. In 1891, 1923, 1962, 1968 and 1975 next year's height increment drops down due to very cool summer temperatures while radial growth holds its rate at average level. These periods share a common pattern; a cool growing season follows two or three warm ones. Similarly, next year's height growth is relatively high in 1966 (150-year-old stand), 1972 (50-year-old stand) and 1985 when a warm summer is followed by a cool growing season. Years 1852-1854 are warm and both radial and next year's height growth are above 

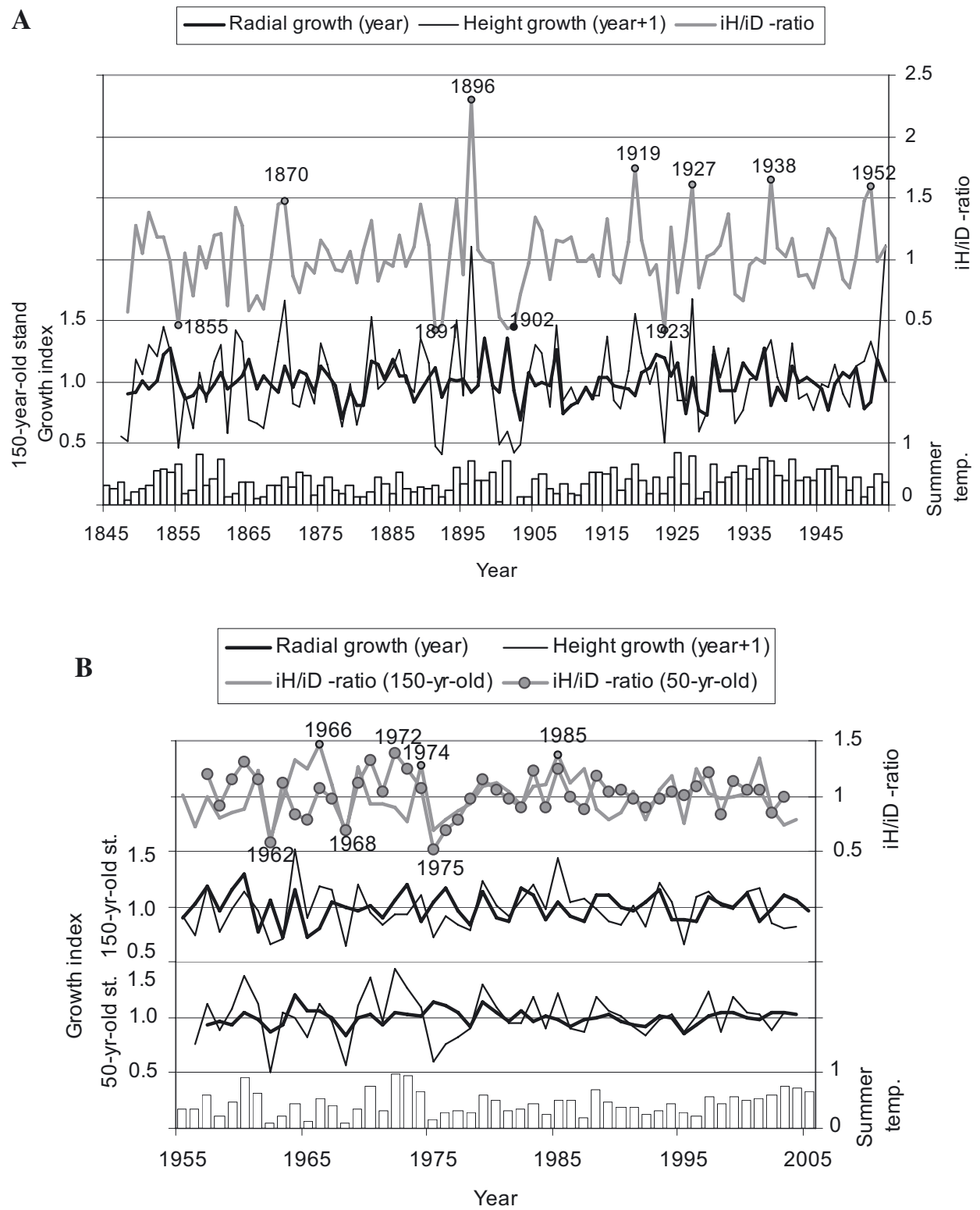

Figure 2. The residual chronology of radial and height growth of the 150 (A) and 50-year-old Scots pine (B). Height-growth chronologies lagged by one year. Ratio of height and radial-growth residual chronologies of the 150-year-old Scots pine from 1845 to 1954 (A) and of the both (50 and 150-year-old) stands from 1955 to 2004 (B). Summer temperature index (June-August temperature weighted by July temperature and scaled to 0.0-1.0) is presented as a bar chart.

average level, but height growth in year 1856 is very low although the previous season, year 1855 , is warmer-thanaverage and radial growth is near average. July 1899 is warm but the next summer and particularly July 1900 is among the coldest of the last two centuries. The following years 19011904 are rather uncommon because next year's height growth is suppressed in spite of very warm season 1901 while radial growth responds to this warm season and drops down due to cool seasons 1902-1903. July temperatures in 1913-1915 are above average but height growth is below average until 1916. Height growth in year 1953 in 150-year-old stand is high in spite of rather cool summer 1952. Take note that June 1953 is the warmest of the whole century according to Ivalo. The 150year-old stand does not react to warm summer temperature in 1972. Growing season 2002 is very warm in northern Finland, but height growth in 2003 is only mediocre.

The temperature sensitivity of radial and height growth was further examined by screening for the temperature period that yields the highest correlation with the four residual growth chronologies (radial and height growth of both stands). Four chronologies and two temperature period definitions - based on Julian days (DD) and relative growing-degree-days (GDD) - resulted in eight separate optimization tasks. The biggest improvement achieved by incorporating DD or GDD was in 
Table VII. The highest correlation coefficient between residual chronology and the mean temperature of current (radial growth) or previous growing season (height growth) for years 1961-2003/2004. The start and end of the temperature period that yields the highest correlation coefficient is defined as months (MM), days (DD), or relative growing-degree-days (GDD\%) and selected using a direct-search optimization.

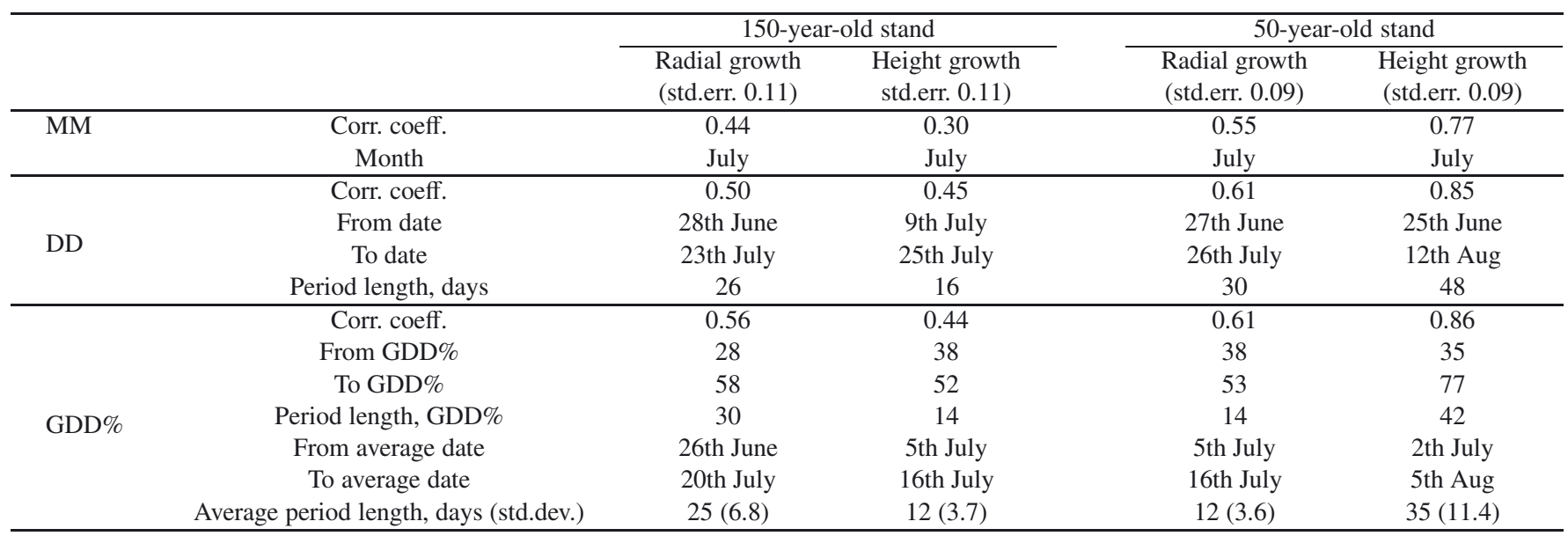

correlation coefficients of the height growth chronology of the 150-year-old stand (Tab. VII). The lengths of DD periods were 16-48 days and included most of July. They were the longer the stronger was the dependence on growth. GDD periods yielded similar correlations but with the 50-year-old stand they were shorter when expressed as Julian days.

\section{DISCUSSION}

The growth of the stands differed substantially from each other. Both height and radial growths of the 50-year-old stand were higher, reaching their maximum annual growth rates much earlier than the ones of the 150-year-old stand. Height growth was more sensitive to previous July mean temperature in the 50 than 150-year-old trees. Most likely the differences between the naturally born stands are due to their silvicultural and management history. The 50-year-old trees have grown as dominant trees since sapling stage. The 150 -year-old trees were dominant ones at the time of sampling but their early silvicultural history is less known that brings more uncertainty to the conclusions. Varying age structure is typical for naturally regenerated stands in northern Finland, and it can be assumed that the sample trees have been suppressed and shadowed by emergent trees during their early growth but became dominant or codominant trees during their mature phase due to selection felling. It is obvious that selection fellings took place especially after the road to Ivalo was opened in 1914. This assumption is supported by the diameter growth that rises into a higher level during 1915-1930. However, this period is known as a time of highly increasing growth throughout northern Finland (Mikola, 1952) after the severe climatic decline in trees' growth and health status at the beginning of the 20th century (Andersson, 1905). It is also possible, even obvious that the growth-limiting factors are not the same throughout the last 150 y (Tuovinen et al., 2009).

The number of the 150-year-old sample trees is low compared to many radial growth studies. On the other hand, the length of the height-growth series is exceptional; over-decadal long series are rare (Insinna et al., 2007; Lindholm et al., 2009; Pensa et al., 2005). Previous studies have shown that ten trees are enough to describe the development of height growth in a stand (Jalkanen et al., 2000). Therefore, the sample size can be considered adequate.

Prewhitening of time series is usually done by removing the autocorrelation with autoregressive (AR), moving-average (MA) or mixed ARMA models. In this study the most common autocorrelation model recommendation for individual tree growth was AR(1). The length of the series affected the complexity of AR model; when analysing the 150-year-old trees, longer lags and moving-average components were also recommended. According to Monserud and Marshall (2001) high-order ARMA models are rarely needed in tree-ring studies. Monserud (1986) concluded that simple two-parameter models describe the autocorrelation structure properly. For example, Monserud and Marshall (2001) applied only the first and second-order autoregressive (AR) and moving-average (MA) models as well as the mixed ARMA first-order model. Based on the 50-year-old trees it can be concluded that there is more feedback from the previous years in radial than height growth. The results from the analysis of the 150-year-old trees indicate only a small difference in autocorrelation between radial and height growth. The differences between the 50 and 150-year-old stands may be partly due to different growth levels; there seems to be fewer limiting factors in the younger than the older trees. Hence, also the impact of temperature is clearer in the 50 than 150-year-old stand. In general, high autocorrelation means lower sensitivity to high-frequency exogenous factors such as temperature during different parts of the growing season.

The confidence of the radial and height-growth chronologies was about the same, but the mean sensitivity was higher in height than radial growth. This reflects the high-frequency signal in height growth indicating its strong response to changes in climate. The high sensitivity of height growth was evident 
also when cross-correlating residual chronologies and mean monthly temperatures. The correlation coefficient between height-growth chronology of the 50-year-old stand and the mean temperature of the previous July was high, $r=0.75$. The respective coefficient from the 150-year-old stand was not as high $(r=0.38)$ but equally significant considering the much smaller standard error of the long growth series. Generally, the relation between growth chronologies and mean monthly temperatures agrees well with earlier studies of Scots pine growth at high latitudes (Jalkanen and Tuovinen, 2001; Junttila, 1986; Junttila and Heide, 1981; Salminen and Jalkanen 2005). The July mean temperature affects statistically significantly radial growth of the same season and height growth of the next season. This results also in the growth models where July temperature as an additional variable effectively decreased the direct cross-dependence of radial and height growth.

Although the current year's radial growth and next year's height growth is largely controlled by the July temperature, their growth variation does not necessarily follow each other. One obvious reason for that is that temperature is just one of the factors controlling growth of the main trunk, and others such as water availability and resource allocation to generative processes may have different influence on radial than height growth. Second, height growth is more sensitive to changes in July temperature. Third, although the timing of phenological events of height and radial growth has some common features (Salminen and Jalkanen, 2007; Seo et al., 2010), the actual effective temperature period is not exactly the same for these two growth components. Selection of temperature periods that give the best fit with the growth chronologies confirms this. However, results from the younger stand did not apply in the older stand and vice versa. Those periods yielding the highest correlations with radial growth correspond with the phenology of latewood production (Seo et al., 2008) and similarly, those periods giving high correlation with height growth are in agreement with the phenology of bud formation (Salminen and Jalkanen, 2007). However, the start of the growing season during the last few decades has become earlier than before, affecting the growth phenology (Schwartz et al., 2006). Hence, the time of actual growth may have changed (Tuovinen et al., 2009). For example, because growing season starts earlier than it used to do, spring and early summer temperatures may be more valuable for height growth now than in the 20th century. In spite of the occasional "asymmetry" in annual height and radial growth, there is a long-term balance that was also statistically distinguishable as a feedback between the residual growth chronologies.

Although height and radial growths were rather similarly autocorrelated, there were several examples that a cool growing season follows two or three warm growing seasons and radial growth maintains its level during the cool year while height declines. This suggests that radial growth uses carbon storages of previous and favourable years. In general, the lagged effect of several favourable or unfavourable years should be noted although their statistical dependence is difficult to confirm due to the limited length of temperature records. There were also individual years or periods of some years when the dependence between summer temperature and growth was weak. Therefore, other factors than temperature may limit growth.

Temperature periods shorter than a month are more effective variables than mean monthly values, but the improvement is in scale from modest to good at least when applying only Julian days or growing-degree-days as pointers. This approach should be elaborated further by combining days and growingdegree-days simultaneously with longer data sets. Then again, optimization techniques should be applied with care because they simply maximize or minimize the selected objective and ignore causality.

Acknowledgements: We are grateful to Tarmo Aalto, Pekka Närhi and Reino Vierelä for providing technical help. This research was, in part, supported by the EU projects Millennium (Contract 017008 (GOCE)) and PINE (Predicting Impacts on Natural Ecotones, Contract no: EVK2-CT-2002-00136).

\section{REFERENCES}

Aalto T. and Jalkanen R., 1998. The needle trace method. Finn. For. Res. Inst. Res. Pap. 681: 1-36.

Andersson G., 1905. Om talltorkan i öfra Sverige våren 1903. Medd. Statens Skogsf. 3: 449-477.

Bower A.D., Adams W.T., Birkes D., and Nalle D., 2005. Response of annual growth ring components to soil moisture deficit in young, plantation-grown Douglas-fir in coastal British Columbia. Can. J. For. Res. 35: 2491-2499.

Briffa K.R., 1995. Interpreting high-resolution proxy climate data - the example of dendroclimatology. In: von Storch H. and Navarra A. (Eds.), Analysis of climate variability, Applications of statistical techniques, Springer Verlag, Berlin, pp. 77-94.

Briffa K.R. and Jones P.D., 1990. Basic chronology statistics and assessment. In: Cook E.R. and Kairiukstis L.A. (Eds.), Methods of dendrochronology: Applications in the environmental sciences, Kluwer Academic, Dordrecht, pp. 137-154.

Büntgen U., Frank D., Schmidhalter M., Neuwirth B., Seifert M., and Esper J., 2006. Growth/climate response shift in a long subalpine spruce chronology. Trees 20: 99-110.

Cook E.R., Briffa K.R., Shiyatov S., and Mazepa V., 1990a. Tree-ring standardisation and growth-trend estimation. In: Cook E.R. and Kairiukstis L.A. (Eds.), Methods of dendrochronology: Applications in the environmental sciences, Kluwer Academic, Dordrecht, pp. $104-123$.

Cook E.R., Shiyatov S., and Mazepa V., 1990b. Estimation of the mean chronology. In: Cook E.R. and Kairiukstis L.A. (Eds.), Methods of dendrochronology: Applications in the environmental sciences, Kluwer Academic, Dordrecht, pp. 123-132.

Doak C.C.,1935. Evolution of foliar types, dwarf shoots, and cone scales of Pinus. Illinois Biol. Monogr. XIII: 106 p.

Grissino-Mayer H.D., 2001. Evaluating crossdating accuracy: A manual and tutorial for the computer program COFECHA. Tree-Ring Res. 57: 205-221.

Grissino-Mayer H.D., Holmes R., and Fritts H.C., 1993. International tree-ring data bank program library user's manual, Laboratory of tree-ring research, University of Arizona, $76 \mathrm{p}$.

Harvey A.C., 1993. Time series models, Harvester Wheatsheaf, London, $308 \mathrm{p}$.

Holmes R.L., 1983. Computer-assisted quality control in tree-ring dating and measurement. Tree-Ring Bull. 43: 69-78.

Holmes R.L., Adams R.K., and Fritts H.C., 1986. Tree-ring chronologies of western North America: California, eastern Oregon and northern 
Great Basin, with procedures used in the chronology development work, including user manuals for computer programs COFECHA and ARSTAN, Laboratory of tree-ring research, University of Arizona, Tucson, AZ, $182 \mathrm{p}$.

Hustich I., 1948. The Scotch pine in northernmost Finland and its dependence on the climate in the last decades. Acta Bot. Fenn. 42: 1-75.

Hustich I., 1978. The growth of Scots pine in northern Lapland, 1928-77. Ann. Bot. Fenn. 15: 214-252.

Insinna P.A., Götz B., Jalkanen R., and Aas G., 2007. One-hundred-year foliage comparison of Pinus ponderosa and Pinus sylvestris under dry growing conditions in Brandenburg, Germany. Scand. J. For. Res. 22: $149-159$

Jalkanen R., Aalto T., Ojanen M., and Vainio E., 2000. Needle trace method and crown thinning (defoliation) in pines, Final report, EUproject 97.60.SF.005.0, Finnish Forest Research Institute, Rovaniemi Research Station, and University of Turku, Satakunta Environmental Research Center, $30 \mathrm{p}$.

Jalkanen R. and Tuovinen M., 2001. Annual needle production and height growth: better climate predictors than radial growth? Dendrochronologia 19: 39-44.

Junttila O., 1986. Effects of temperature on shoot growth in northern provenances of Pinus sylvestris L. Tree Physiol. 1: 185-192.

Junttila O. and Heide O.M., 1981. Shoot and needle growth in Pinus sylvestris as related to temperature in northern Fennoscandia. For. Sci. 27: 423-430.

Klingbjer P. and Moberg A., 2003. A composite monthly temperature record from Tornedalen in northern Sweden, 1802-2002. Int. J. Climatol. 23: 1465-1494.

Kurkela T. and Jalkanen R., 1990. Revealing past needle retention in Pinus spp. Scand. J. For. Res. 5: 481-485.

Laitakari E., 1920. Tutkimuksia sääsuhteiden vaikutuksesta männyn pituus ja paksuuskasvuun. Referat: Untersuchungen über die Entwirkung der Witterungsverhältnisse auf den Längen und Dickenwachstum der Kiefer. Acta For. Fenn. 17: 1-53.

Lanner R.M., 1976. Patterns of shoot development in Pinus and their relationship to growth potential. In: Cannell M.G.R. and Last F.T. (Eds.), Tree physiology and yield improvement, Academic Press, London, UK, pp. 223-243.

Lanner R.M., 1985. On the insensitivity of height growth to spacing. For. Ecol. Manage. 13: 143-148.

Lindholm M., Jalkanen R., and Salminen H., 2009. High-to-medium frequency reconstruction of summer temperature from annual height increment of Scots pine at the northern timberline since 1846. Dendrochronologia 27: 113-119.
Mikola P., 1950. Puiden kasvun vaihteluista ja niiden merkityksesta kasvututkimuksissa. Summary: On variations in tree growth and their significance to growth studies. Commun. Inst. For. Fenn. 38.5: 1131.

Mikola P., 1952. Havumetsien viimeaikaisesta kehityksestä metsänrajaseudulla. summary: On the recent development of coniferous forests in the timber-line region of northern Finland. Commun. Inst. For. Fenn. 40.2: 1-35.

Monserud R.A., 1986. Time-series analyses of tree-ring chronologies. For. Sci. 32: 349-372.

Monserud R.A. and Marshall J.D., 2001. Time-series analysis of $\delta^{13} \mathrm{C}$ from tree rings. I. Time trends and autocorrelation. Tree Physiol. 21: 1087-1102.

Niinemets Ü., 1997. Acclimation to low irradiance in Picea abies: Influences of past and present light climate on foliage structure and function. Tree Physiol. 17: 723-732.

Pensa M., Salminen H., and Jalkanen R., 2005. A 250-year-long heightincrement chronology for Pinus sylvestris at the northern coniferous timberline: A novel tool for reconstructing past summer temperatures? Dendrochronologia 22: 75-81.

Salminen H. and Jalkanen R., 2005. Modelling the effect of temperature on height increment of Scots pine at high latitudes. Silva Fenn. 39: 497-508.

Salminen H. and Jalkanen R., 2007. Intra-annual height increment of Pinus sylvestris at high latitudes in Finland. Tree Physiol. 27: 13471353.

SAS User's Guide, 2002. SAS/ETS user's guide, version 9, Vol. 1 and 2, SAS Publishing, Cary, NC, 2162 p.

Schwartz M.D., Ahas R., and Aasa A., 2006. Onset of spring starting earlier across the Northern Hemisphere. Glob. Change Biol. 12: 343351.

Seo J-W., Eckstein D., Jalkanen R., Rickebusch S., and Schmitt U., 2008. Estimating the onset of cambial activity in Scots pine in northern Finland by means of the heat-sum approach. Tree Physiol. 28: 105112.

Seo J-W., Salminen H., Jalkanen R., and Eckstein D., 2010. Chronological coherence between height growth and radial growth of Scots pine. Baltic For. 16 (in print).

Tsay R.S. and Tiao G.C., 1985. Use of canonical analysis in time series model identification. Biometrika 72: 299-315.

Tuovinen M., McCarroll D., Grudd H., Jalkanen R., and Los S., 2009. Spatial and temporal stability of the climate signal in northern Fennoscandian pine tree-ring width and maximum density. Boreas 38: $1-12$. 